\title{
Introduction: Re-reading of cultural semiotics
}

In 2002 the Department of Semiotics of the Tartu University got 10 years old. Juri Lotman, the founder of the Department, would have turned 80 in the same year. This was a symbolic reason to invite from all over the world scholars respecting semiotic thinking and/or J. Lotman's scientific legacy to Tartu. So the international conference "Cultural Semiotics: Cultural Mechanisms, Boundaries, Identities” (25.02-2.03.2002) was born.

The conference worked in two major sections. One section was entitled "Cultural semiotics and complex cultural analysis" and its initial point was the situation of culture research disciplines in the beginning of the new century. Dialogue between different disciplines studying culture has been hindered by the absence of a unified theory of culture in world science. Cultural semiotics has the makings of becoming into such methodologically connecting discipline for these trends. Culture research is inseparable from the study of cultural contacts. The globalisation of the world and the integration of Europe make the problem of cultural contacts more and more important. In addition to political dialogue, dialogue between cultures is a theoretical, empirical, and didactic problem. Cultural contacts, cultural mechanisms, cultural boundaries and identities are simultaneously problems of cultural dialogue and dialogue between description languages of culture. It is important to bring together the diversity of contemporary cultural processes and the possibility of studying them from unified scientific positions.

The second section entitled "Russian culture sub speciae Lotmanianae" was, on the one hand, focused at one of the main principles of cultural semiotics according to which the criterion of precise analysis is explication of the viewpoint of researcher. On the other hand the organisation of this section was justified by J. Lotman's principle that any material of a certain culture can provide with impulses for the emergence of new research methods, and empirical analysis can thus bring along theoretical innovation. This does not concern the frames of merely an individual discipline. J. Lotman's activity has proven that the empirical experience of a literary scholar or of a historian can easily transform into theoretical knowledge that of a semiotician. At the same time problems of scientific methodology and the question of the relationship between modes of describing culture and the peculiarities of national cultures exist together for scholars of culture around the world. 
In many disciplines the personality of a scholar and his/her creation as a whole turn into a driving force of a discipline long since a scholar has passed away. There exist scholars the re-reading and re-discovering of whom proves that the future of a science can sometimes wait its time in the past. Julia Kristeva's re-reading of Mikhail Bakhtin created in the 1960s the situation in which Bakhtin's 40 year studies occurred to be as sent from the future. Such re-reading probably waits for several scholars who, due to one reason or another, have not been enough distributed as translations in great languages. Of J. Lotman's predecessors an example of this can be M. Bakhtin's contemporary Juri Tynjanov.

A reason for re-reading can be a wish to get rid of the cultural layer and returning to the values of the original text that has turned into hardly comprehensible because of multiple interpretations. So has Jerzy Pelc expressed a wish to return to Charles Sanders Peirce: "I wish to find out what he actually had in mind. I therefore ask questions. And I would very much like to hear competent answers to these questions, but answers that are not formulated according to the rules of Peirce's style and poetics which his followers and commentators sometimes adopt as their own" (Pelc 1990: 4).

Roland Barthes can be an example of a recent re-reading; different parts of his legacy occur again innovative in the hands of several researchers. Jonathan Culler, for example, stresses the value of a theoretician and a semiologist in this "back to Barthes" movement: "It seems to me that the essential feature of Barthes's genius is to have discovered the heuristic function of systematicity and of the requirement of explicitness. [...] Systematicity is, first and foremost, a means of estrangement, verfremdung" (Culler 2001: 440). The innovative nature of R. Barthes is condensed in the notion of text. It is this notion that connects R. Barthes and J. Lotman, and J. Culler's following words might characterise both scholars: "A first consequence of this interdisciplinary reorientation was the positing of the methodological equivalence of different cultural products, whether literary works, fashion captions, advertisements, films, or religious rituals: all can be considered as text" (Culler 2001: 442). Since the concept of text is paired with the notion of work, J. Culler recognises two perspectives for R. Barthes' treatment of text. First, "work and text would be two different concepts of the object of study. [...] Alternatively, work and text could be two different classes of objects (roughly the traditional and the avant-garde)" (Culler 2001: 444). In contemporary methodological searches Barthes thus occupies an important place, although this does not concern all his works: "We may often need to read Barthes against the grain to preserve the theoretical and methodological gains that he himself risks dissipating or concealing in such slides into mystification or nostalgia; but this sort of vigilance is precisely what we can learn when we go "back to Barthes", or rather, back to the early writings of Roland Barthes" (Culler 2001: 445).

Re-reading from another viewpoint can take to the equalisation of semiology and sociology: "Barthesian semiology was inevitably and invariably a 
sociology" (Polan 2001: 456). From the side of semiotics, however, an opposite attitude is possible. An example of that can be John Deely's fear in an argument with Umberto Eco, especially in connection with the bringing close together sign and sign-function: "As we shall see over the course of this discussion, this amounts to proposing the elimination of semiotics in the name of semiotics, or, what amounts to the same thing, the restriction of semiotics to the horizon of semiology" (Deely 2001: 705).

J. Deely's re-reading of Eco also takes to reformulation of the famous definition "the possibility of lying is the proprium of semiosis" (Eco 1977: 59): "This is well put, if one sided, since the possibility of expressing any truth is equally the proprium of semiosis. Since the sign is that which every object presupposes, and since semiotics studies the action of signs, perhaps the best definition of semiotics would be: the study of the possibility of being mistaken" (Deely 2001: 733). Viewing semiotics against the background of the distinction of the notions of discipline and field, or the theoretical and the applied aspects, J. Deely tries to defend the notion of the sign for the sake of holistic semiotics: "[...] the notion of signum is broader and more fundamental than Eco's notion of sign-function, and nothing is more important in the long run than a proper clarification and laying of the foundations for the enterprises of semiotics. [...] sign is the universal instrument of communication, within oneself or with others equally" (Deely 2001: 733).

The disciplinary importance of the problem is indicated by Jerzy Pelc's attempt to re-read works by $\mathrm{Ch}$. S. Peirce and Ch. Morris, and to answer the same questions that bothered J. Deely. Viewing semiosis as sign process and semiotics as the science or knowledge of semiosis, J. Pelc presents an understanding of the object of semiotics: "The object of semiotics, in one meaning of this term, are semiosic activities and the products thereof, i.e., semiosis and signs together with their semiosics" (Pelc 2000: 431). Through re-reading Peirce and Morris J. Pelc also articulates the notion of semiosis: "I treat semiosis as activities which in some cases produce signs together with selected semiosic properties or semiosic relations thereof, and sometimes semiosics, i.e., the totality of semiosic properties of these signs or the totality of semiosic relations containing the signs as their elements" (Pelc 2000: 428). From another viewpoint J. Deely, for example, treats the same problems through the concept of intersemiosis: "[...] human understanding finds its operational existence initially in terms of the intersemiosis which perception makes possible as developing around a sensory core" (Deely 2002: 68).

These dissimilar re-readings reflect well the dependence of any discussions on metalanguages that are the means of communication and selfcommunication of those participating in the discussion. Thus science does not depend that much on culture a part of which it is. Even if discussion or dialogue goes on in the framework of one discipline, scholarly multilingualism is preserved, because the sources of metalanguage, including texts and authors re-read, are very diverse. At the same time (meta)linguistic identity problems emerge inside different traditions. Talking about the semiotics of 
the new century, Umberto Eco brings an example from Russian literature. Lev Tolstoi's "War and Peace" is a work in which Russian common people speak common Russian, and a vast majority of nobility speak French. Tolstoi's semiotics of the own and the alien is also based on this linguistic difference. Yet what happens to this work at translation into French, loses as a separator of the dissimilar sociocultural worlds of natural language (Eco 2001: 291-292). The same holds true for metalanguages and scientific tradi-

tions. Innovation and innovation emerging via re-reading may gain support from metalinguistic dissimilarity, and may stay unnoticed in the case of the lack of strangeness.

Juri Lotman's legacy is not enough known outside the boundaries of Russian. However, his scientific potential is ever-growing in spite of him not being amongst us already for nearly ten years. Not all his conceptually important works are known in English and thus his more holistic treatment lays ahead in the future. A very good specialist of Lotman's work, Karl Eimermacher, cognised the importance of Lotman's semiotics for holistic study of culture already in the 1970s, and called this a semiotic version of integrative culturology (Eimermacher 1997: 229). Irene Portis-Winner has long and fruitfully sensed her ethnological and culturo-semiotic studies by the help of Lotman. In her last book she finds Lotman's notion of semiosphere as a creator of holistic perspective: "Lotman`s concept of the semiosphere subsumes all aspects of the semiotics of culture, all the heterogeneous semiotic systems or "languages" that are constantly changing and that in an abstract sense, have some unifying qualities" (Portis-Winner 2002: 63; cf. also PortisWinner 1999).

Thus there are reasons to deal more actively with re-reading J. Lotman, and to identify his innovative potential. There already have appeared and are appearing studies based on systematic knowledge of J. Lotman's legacy. So Edna Andrews stresses the semiosic aspect of J. Lotman's concept of semiosphere: "The semiosphere may appear to be a semiotic unity at its highest level, but in fact it is a conglomerate of boundaries defining everchanging internal and external spaces. Thus, there can be no "language" or "memory" for Lotman without the guarantee of semiosis in the form of the semiosphere" (Andrews 1999: 13). From here Lotman's importance is seen: "Lotman's extensive work on the semiosphere and the semiotics of communication provide some invaluable concepts and categories that offer insights into the structural principles of semiosis" (Andrews 1999: 8).

Boguslaw Zylko stresses, from the perspective of Lotman's evolution, that the concept of semiosphere signifies transfer from static to dynamic analysis, and the basis of this transfer is understanding the relationship between holism and heterogeneity: "The shift, from the conception of culture as a bundle of primary and secondary modelling systems to the notion of semiosphere, is also a shift from static to dynamic thinking. If we took the former approach, culture would resemble a motionless unit made up of semiotic systems; whereas if we follow the semiospheric approach, culture 
takes the shape of a heterogeneous whole bustling with multiple rhythms of development and transient dominants" (Zylko 2001: 400). Dynamism is stressed also by Floyd Merrell in his comparison of Peirce and Lotman and treatment of biosemiosphere: "Cultures are processes, never products; they are codependently arising becoming, not cause-and effect sequences; they are events, not things moving along like trains on a track; they are perpetually self-organizing into unseen and unseeable wholes, rather than predictable wholes and their parts in terms of static and statistical averages. They are semiosis at its best, though, unfortunately, occasionally at its worst" (Merrell 2001: 400).

In works by colleagues I consciously bring forward these aspects that point at the change in culture as a research object in connection with the methodological possibilities of a discipline. I would like to add another developmental trait in connection with history and evolution. In 1984 Walter A. Koch wrote in the foreword of his series of Bochum Publications in Evolutionary Cultural Semiotics on the notion of culture that it is "[...] a phenomenon whose true integrative potentialities have not yet been fully discovered or explored. For a semiotics thus conceived, structure and process are not different phases of reality and/or sciences but rather mere faces of a unitary field. In the view of this series, then, any fruitful attempt at semiotic analysis will be based on premises of macro-integration - or evolution and of micro-integration - culture" (Koch 1989: v). In 1992 Lotman wrote in the foreword of Sign Systems Studies vol. 25 that was the last appearing in his lifetime: "During the past decades semiotics has changed. One achievement on its hard path was unification with history. The cognition of history became semiotic, but semiotic thinking obtained historic traits. [...] Semiotic approach tries to avoid the conditional stopping of the historical process" (Lotman 1992: 3). Lotman also concludes that "each generation has a language for describing yesterday and principally lacks a language for tomorrow" (Lotman 1992: 4). In between these there is today in which the description of culture is, on the one hand, a problem of metalevel, i.e. that of the level of scholarship or criticism. On the other hand culture works, as living through, on the level of self-description, be it the case of an individual or collective consciousness.

An important ontological feature of culture as a complex object of study is the coexistence of different description. As a result of descriptive processes this allows to talk about cultural self-models. Cultural self-description as a process can be viewed in three directions. Culture's self-model is the result of the first, and its goal is maximum approach to the actually existing culture. As a second result there emerge cultural self-models that differ from ordinary cultural practice and have been designed for changing that practice. A third result lays in those self-models that exist as ideal cultural self-consciousness separately from culture and have not been aimed at it. By this Lotman does not exclude conflict between culture and its self-models. At the same time it 
is exactly the self-descriptions that allow to reach the notion of cultural unity (Lotman 2000a: 420). Cultural unity, in turn, points at personality.

Lotman views culture as a collective intellect and compares it with both individual and artificial intellect. The measure of intellect is formed by two main features - to create a whole out of a heterogeneous association and to create novelties. Both features are inseparable from the notion of personality: "A thinking structure must form a personality, i.e. to integrate oppositional semiotic structures in one whole" (Lotman 2000c: 573). In 1980s Juri Lotman described creativity, relying on Ilya Prigogine. The article "Culture as a subject and object for itself" maintains that: "The main question of cultural semiotics is the problem of the emergence of meaning. We call the emergence of meaning both the ability of culture as a whole and its parts to put from its "output" out nontrivial new texts. New texts are the texts that emerge as results of irreversible processes (in Ilya Prigogine's sense), i.e. texts that are unpredictable to a certain degree" (Lotman 2000b: 640).

In the article "The phenomenon of culture" (Lotman 2000c) Juri Lotman creates foundation for theoretical construction of the following years. He offers a typology that has not been yet properly sensed the best articulation of which that article is. The basis for the typology is distinction of the static and dynamic aspects of cultural languages. From the static aspect cultural languages divide into the discrete and the continual (iconic-spatial), and for Juri Lotman this forms the semiotic primordial dualism. In discrete languages sign comes first and meanings are created through the meanings of signs. In continual languages text comes first and meaning emerges through holistic text that integrates even the most heterogeneous elements. These are the two languages between which it is difficult to create translatability. Difficulties of translatability and the impossibility of reverse translation turn any mediating activity between these languages into creative and are thus the basis for creativity.

In dynamism the simultaneity of the two processes in culture is important. On the one hand in different fields of culture there goes on specialisation of cultural languages as a result of autocommunication and identity searches. On the other hand on the level of culture as a whole there emerges integration of cultural languages as a possibility of self-communication and self-understanding. Yet the dynamism of integration is revealed in the simultaneity of the two processes. From the one side in different parts of culture there are being created self-descriptions and alongside with them also metadescriptions or descriptions from the position of culture as a whole. This is integration though autonomies. From the other side their goes on diffusion, creolisation of cultural languages due to the communication between different parts of culture. Creolisation is a feature of dynamism and an intermediary stage at reaching a new autonomy or pure (self)description. Thus Juri Lotman has raised Juri Tynjanov's evolution model to a new level and created an understanding of culture not as static system but a collective intellect in 
continuous development that is characterised by the need of cognising its identity and expressing itself, i.e. being creative.

I already hinted at U. Eco's example of the sociocultural role of the French language in L. Tolstoi's War and Peace. Russian and French signify different worlds and dissimilar identities and the impossibility of distinguishing between them in translation into French demolishes boundaries between these worlds. J. Lotman, however, liked to use another example from the same work: the scene in which a Russian ranker enters a dialogue with a captured French soldier and does it in an invented abracadabra language. The reason for that is his understanding of French as a spoilt Russian. And even though one of the languages used in that dialogue does not exist the dialogue is still successful. So do cultures exist by having autonomous languages communicating inside them as creolised complexes consisting of fragments of different languages. Communication itself creates the need to derive a new language of the creolised association, for the need for autonomy and identity increases when getting in touch with another autonomy and identity. Dialogue creates identity. If continuing the situation presented by Tolstoi, the meeting of French and the nonexistent or spoilt Russian would be followed by the gradual creolisation of French and Russian, mutual fragmentary translation that in the ideal case would lead to equal translatability of both languages. If need for dialogue decreases or disappears due to certain reasons, one of the partners can shift to the periphery, i.e. to become invisible in culture. This is what happened in Russia where the niche of cultural semiotics was taken over by the postmodern paradigm (see Torop 2001).

Studying culture is made difficult by the similarity of processes on the object level and different metalevels. Autonomy and creolisation are visible in relationships between different fields of culture, ways of self-description of different fields, and metadescriptive levels of cultural analysis. Thus it is regular to meet, for example, the notion of representation side by side with semiosis at trials of defining the object of semiotics. So, from the position of applied analysis, it has been stated that semiotics "is an autonomous science that aims to investigate semiosis - the capacity to produce and comprehend signs - and representation - the activity of using signs to make messages and meanings (Beasley, Danesi 2002: 32). Similarly characteristic is Göran Sonesson's statement that "the project of the semiotics of culture is a sociological project. In this sense, it may be seen as a foundation for that study of the life of signs in society, from which Saussure finally opted out; but also, more importantly, as a new start for the study of dialogicity uniting the ego and the alter, which was sketched long ago, in so many divergent ways, by the members of the Bakhtin circle" (Sonesson 1998: 108).

At the meeting of culture and disciplines studying it there emerge questions the new century must seek or reformulate answers for. The first circle of questions concerns culture as a complex research object and connects with disciplinary possibilities in culture research trends. Can culture as a complex object be transformed into one or several disciplinary objects of study? From 
here emerges the quest for a coherent complex science. Françoise Rastier has raised a question of a universal trans-semiotics and distinguishes between two poles in connection with culture research: the pole of sciences of culture (sciences de la culture) is exemplified by Ernst Cassirer and the pole of semiotics of cultures (sémiotique des cultures) by the Tartu school. In between the two poles there remain questions: one or many sciences? culture or cultures? (Rastier 2001: 163). The second circle of questions connects with relationships between disciplines studying culture. Is it possible to imagine culture studying disciplines in terms of hierarchy, can any of them, e.g., cultural semiotics, be in the role of a foundation discipline methodologically? I.e., culture-studying disciplines, their dialogue abilities with both the object of study and neighbouring disciplines ought to be objects of analysis separately. Thus there is to be answered the question what are connections between disciplinariness on the one hand, and multi-, trans-, inter-, and dedisciplinariness on the other. Culture as an object of study and culture research sciences as objects of study — in both cases it is suitable to recall the picture emerged as Umberto Eco's re-reading of Lotman: "If we put together many branches and great quantity of leaves, we still cannot understand the forest. But if we know how to walk through the forest of culture with our eyes open, confidently following the numerous paths which criss-cross it, not only shall we be able to understand better the vastness and complexity of the forest, but we shall also be able to discover the nature of the leaves and branches of every single tree" (Eco 2000: xiii).

The present volume mostly contains proceedings of the conference dedicated to the memory of Juri Lotman. There are enough of them also for another volume. However, side by side with presentations here are other works that have arrived the editorial as results of different dialogues. I would like to mention separately only one of them. In the beginning of cultural semiotics during 1960-70s the development of semiotics was importantly influenced by a general tension field that connected different regions and centres of semiotics that created dialogues primarily via translations, for direct communication was not always possible. The re-reading of M. Bakhtin's works in the world there was accompanied with interest from the side of the Soviet Union to Paris and especially works by Julia Kristeva. Sign Systems Studies is probably the first publication in the Soviet Union that started to introduce J. Kristeva's ideas. I have read J. Kristeva's and some other French colleagues' books in French at J. Lotman's home library. Today it is a pleasure to maintain that the old dialogue is continuing through J. Kristeva's contribution to Sign Systems Studies. In science time is not the essence. Far more important is phatic communication, readiness for dialogue, expectancy of dialogue even when years can take dialogue partners into different centuries. We remember J. Kristeva's obituary to J. Lotman (Kristeva 1994). It is all the more pleasant to once again assert that science is dialogue and neither is afraid of time. 


\section{References}

Andrews, Edna 1999. Lotman's communication act and semiosis. Semiotica 126(1/4): 1-15.

Beasley, Ron; Danesi, Marcel 2002. Persuasive Signs: The Semiotics of Advertising. Berlin: Mouton de Gruyter.

Culler, Jonathan 2001. Barthes, Theorist. The Yale Journal of Criticism 14(2): 439-446.

Deely, John 2001. Four Ages of Understanding: The First Postmodern Survey of Philosophy from Ancient Times to the Turn of the Twenty-first Century. Toronto: Toronto University Press.

- 2002. What Distinguishes Human Understanding? South Bend: St. Augustine's Press.

Eco, Umberto 1977. Theory of Semiotics. London: The Macmillan Press Ltd.

- 2000. Introduction. In: Lotman, Yuri, Universe of the Mind: A Semiotic Theory of Culture. Bloomington: Indiana University Press, vii-xiii.

- 2001. La semiotica del terzo millenio e gli incontri di culture. In: Calefato, Patrizia; Caprettini, Gian Paolo; Colaizzi, Giulia (eds.), Incontri di culture: La semiotica tra frontiere e traduzioni. Torino: UTET Libreria, 287-293.

Eimermacher, Karl 1997 = Аймермахер, Карл, Знак. Текст. Культура. Москва: Дом интеллектуальной книги.

Koch, A. Walter 1989. Bochum Publications in Evolutionary Cultural Semiotics: Editorial. In: Koch, Walter A. (ed.), Culture and Semiotics. Bochum: Studienverlag Dr. Norbert Brockmeyer, v.

Kristeva, Julia 1994. On Yury Lotman. PMLA 109(3): 375-376.

Lotman, Juri 1992 = Лотман, Юрий. От редколлегии. Труды по знаковым системам (Sign Systems Studies) 25: 3-4.

- 2000а = Лотман, Юрий. Проблема "обучения культуре" как типологическая характеристика. In: Лотман, Юрий, Семиосфера. Санкт-Петербург: Искусство-СПБ, 417-425.

- 2000b = Лотман, Юрий. Культура как субъект и сама-себе объект. In: Лотман, Юрий, Семиосфера. Санкт-Петербург: Искусство-СПБ, 639647

- 2000с = Лотман, Юрий. Феномен культуры. In: Лотман, Юрий, $\mathrm{Ce}$ миосфера. Санкт-Петербург: Искусство-СПБ, 568-580

Merrell, Floyd 2001. Lotman's semiosphere, Peirce's categories, and cultural forms of life. Sign Systems Studies 29(2): 385-415.

Pelc, Jerzy 1990. Several questions to experts in Peirce's theory of signs. Versus 55/56: $13-28$

- 2000. Semiosis and semiosics vs. semiotics. Semiotica 128(3/4): 425-434.

Polan, Dana 2001. Inexact science: Complexity and contradiction in Roland Barthes's "Classic Semiology". The Yale Journal of Criticism 14(2): 453-462.

Portis-Winner, Irene 1999. The dynamics of semiotics of culture; its pertinence to anthropology. Sign Systems Studies 27: 24-45.

- 2002. Semiotics of Peasants in Transition: Slovene Villagers and Their Ethnic Relatives in America. Durham: Duke University Press. 
Sonesson, Göran 1998. The concept of text in cultural semiotics. Sign Systems Studies 26: 83-114.

Rastier, François 2001. Sémiotique et sciences de la culture. LINX 44(1): 149166.

Torop, Peeter 2001. New paradigm of culture and/as new paradigm of describing culture: The Russian aspect. In: Mochizuki, Tetsuo (ed.), Russian Culture on the Threshold of a New Century. Sapporo: Slavic Research Center, Hokkaido University, 33-43 [in Russian].

Zylko, Boguslaw 2001. Culture and semiotics: Notes on Lotman's conception of culture. New Literary History 32(2): 391-408.

Peeter Torop 